\title{
РЕЦЕНЗІЯ
}

на монографію "Механізм формування інтелектуального капіталу дипломатичної служби як складова державного управління: теорія і практика" (автор: Р. В. Палагусинець, к. е. н., заступник керівника відділу Управління забезпечення міжпарламентських зв'язків Апарату Верховної Ради України)*

DOI: $10.32702 / 2306-6814.2021 .4 .122$

\section{REVIEW OF THE BOOK: "MECHANISM OF FORMATION OF THE INTELLECTUAL CAPITAL OF THE DIPLOMATIC SERVICE IN THE PUBLIC ADMINISTRATION" \\ (author: R. Palagusynets, Ph.D. in Economics)}

Монографічна праця Р. В. Палагусинця присвячена сучасній актуальній проблемі - дослідженню багатофрункціональних проблем формування інтелектуального капіталу дипломатичної служби, кадрової політики та механізмів добору персоналу до дипломатичної служби.

У монографої досліджується широке коло питань, що стосуються впливу державного управління на кадрову політику дипломатичної служби, інтелектуалізація праці співробітників дипломатичної служби та основні проблеми у формуванн людського та інтелектуального капіталу системи дипломатичної служби.

Автором запропоновано власне бачення шляхів підвищення ефективності управління людським капіталом дипломатичної служби з метою фрормування інтелектуального капіталу, що знайшло своє практичне відображення в прийнятому норматив-правовому акті.

У монографії досліджено розвиток поняття "інтелектуальний капітал", визначено поняття "інтелектуальний капітал системи дипломатичної служби", концептуальні засади механізму формування інтелектуального капіталу дипломатичної служби в державному управлінні. Запропоновано нові підходи до формування інтелектуальної еліти дипломатичної служби, організаційного та інституційного забезпечення механіз му формування інтелектуального капіталу дипломатичної служби на національному рівні.

Монографрія складається з передмови, п'яти розділів, висновків та списку використаних джерел. У першому розділі "Теоретико-методологічніі засади поняття дипломатичної служби та інтелектуального капіталу дипломатичної служби" автор розглядає питання визначення категорій "дипломатична служба", "інтелектуальний капітал", "інтелектуалізація", "державне управління", "інтелектуальний рівень дипломатів" та інших, що складають понятійно-категоріальний апарат дисциплін "Кадрова політика дипломатичної служби", "Історія дипломатії", "Основи економічної теорії", "Теорія державного управління" тощо.

Другий розділ "Аналіз кадрового потенціалу дипломатичної служби та основні аспекти механізму формування інтелектуального капіталу дипломатичної служби" присвячено дослідженням основних аспектів механізму формування інтелектуального капіталу дипломатичної служби. На підставі досліджень автор пропонує власний механізм для систематичної оцінки, а саме: моніторинг інтелектуального капіталу дипломатичної служби. Також досліджено стан кадрового потенціалу дипломатичної служби за економічної безпеки України за період 2017-2020рр. за звітними та статистичними даними кадрової політики дипломатичної служби, автор зазначає також, що охопити більший період не вдалось за відсутності статистичних даних.

У третьому розділі "Кадрова політика в системі дипломатичних служб та управління розвитком людського капіталу в системі дипломатичних служб " досліджено механізми управління розвитком людського капіталу дипломатичної служби та механізм добору кадрів для роботи в дипломатичних службах. Виокремлено чинники, що негативно впливають з боку державного управління на формування інтелектуального капіталу дипломатичної служби.

У четвертому розділі "Інтелектуалізація праці, зарубіжний досвід добору кадрів для дипломатичної служби" проаналізовано досвід розвинених країн у кадровій політиці та доборі кадрів до дипломатичних служб загалом та з урахуванням пандемії, а також можливість його імплементації у вітчизняну практику.

У п'ятому розділі "Шляхи підвищення ефективності управління людським капіталом, пріоритети розвитку інтелектуального капіталу і формування інтелектуальної еліти дипломатичної служби", який $є$ заключним, автор описує власне бачення основних напрямів кадрової політики дипломатичної служби України та теоретичну модель механізму формування інтелектуального капіталу дипломатичної служби в державному управлінні.

Кожен розділ монографрії завершують логічні висновки, які відображають результати виконаного дослідження.

Рецензована монографія, безперечно, заслуговує високої оцінки і займе достойне місце серед досліджень у галузі теорії розвитку системи дипломатичної служби та державного управління. Ї̈̈ результати можуть бути використані під час викладання курсів "кадрова політика та державна служба", "теорія національної безпеки", "державне управління в системі дипломатичної служби", а також у теоретичних дослідженнях з проблем кадрової політики дипломатичної служби, управління людським потенціалом державного управління.

Рецензент вважає, що монографія Р.В. Палагусинця за своїм науковим рівнем, обсягом та оформленням повністю відповідає вимогам МОН України і рекомендується до друку як сучасна наукова праця в галузі державного управління, публічного управління та врядування.

Рецензент:

М. В. Сіцінська, д. держ. упр., головний науковий співробітник відділу з координації наукових заходів, міжнародного співробітництва та грантової діяльності Хмельницького університету управління та права імені Леоніда Юзькова.

* Палагусинець Р. В. "Механізм формування інтелектуального капіталу дипломатичної служби як складова державного управління: теорія і практика : монографія. Кам'янець-Подільський : Видавець ТОВ "Друкарня "Рута", 2020. 432 с. 